\title{
DOES THE AGING POPULATION BECOME A CONSTRAINT TO THE GROWTH OF TURKISH ECONOMY? NEW EVIDENCE FROM TIME SERIES ANALYSIS
}

\author{
Eyyup ECEVIT* \\ Murat ÇETIN*** \\ Özge YILDIZ ${ }^{* * *}$ \\ Rabia DOĞAN ${ }^{* * * * * *}$
}

\begin{abstract}
This study deals with the relationship between population aging and economic growth in Turkey during 1970-2018 and includes domestic savings, consumption expenditures, and financial development in the growth specification as additional variables. The Johansen and ARDL bounds test for cointegration analysis were used. Moreover, DOLS and CCR estimators were used to estimate the long-run coefficients. The VECM causality procedure was employed for causality analysis. The findings revealed that the variables are cointegrated. The findings showed that population aging, and financial development negatively affected economic growth while domestic savings and consumption expenditures were positively related to economic growth in the long-run. The findings also indicated that bidirectional causality exists between all the independent variables and economic growth in the long-run. Therefore, this study can provide several policy implications to speed economic growth in the Turkish economy.
\end{abstract}

Keywords: Population Aging, Economic Growth, ARDL, Causality Test, Turkey.

${ }^{*}$ Prof. Dr. Erciyes Üniversitesi, İktisadi ve İdari Bilimler Fakültesi, İktisat Bölümü, ecevit@erciyes.edu.tr. https://orcid.org/0000-0002-2417-4043.

${ }^{* *}$ Prof. Dr. Namık Kemal Üniversitesi, İktisadi ve İdari Bilimler Fakültesi, İktisat Bölümü, mcetin@nku.edu.tr. https://orcid.org/0000-0002-7886-4162.

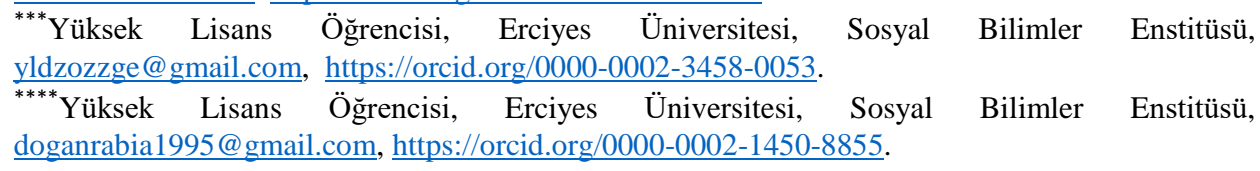




\title{
YAŞLANAN NÜFUS TÜRKIYE EKONOMISININ BÜYÜMESINE ENGEL OLUYOR MU? ZAMAN SERISİ ANALIZINDEN YENI KANITLAR
}

\begin{abstract}
öz
Bu çalışma, Türkiye'de 1970-2018 döneminde nüfusun yaşlanması ile ekonomik büyüme arasındaki ilişkiyi ele almakta ve ek değişkenler olarak büyüme spesifikasyonunda yurt içi tasarrufları, tüketim harcamalarını ve finansal gelişmeyi içermektedir. Eşbütünleşme analizi için Johansen ve ARDL sınır testi kullanıldı. Ayrıca, uzun dönem katsayılarını tahmin etmek için DOLS ve CCR tahmin edicileri kullanıldı. Nedensellik analizi için VECM nedensellik prosedürüne başvuruldu. Bulgular, değişkenlerin eşbütünleşik olduğunu ortaya koymuştur. Sonuçlar, nüfusun yaşlanması ve finansal gelişmenin ekonomik büyümeyi olumsuz etkilediğini, yurtiçi tasarrufların ve tüketim harcamalarının ise uzun vadede ekonomik büyümeyle pozitif yönde ilişkili olduğunu göstermiştir. Ayrıca, uzun vadede tüm bağımsız değişkenler ve ekonomik büyüme arasında çift yönlü nedenselliğin var olduğunu göstermiştir. $\mathrm{Bu}$ nedenle, bu çalışma Türkiye ekonomisinde ekonomik büyümeyi hızlandırmada çeşitli politika uygulamaları sağlayabilir.
\end{abstract} Türkiye.

Anahtar Kavramlar: Nüfus Yaşlanması, Ekonomik Büyüme, ARDL, Nedensellik Testi,

\section{INTRODUCTION}

The aging of the world population has undergone significant changes in the age structure of the population and its effects on the economy have been debated recently. Population aging poses a bigger problem, especially in developed countries rather than in developing countries, but this problem is also increasing in developing countries. Considering the change in fertility and death rates, a significant decrease was observed in the world between 1960-2018 overall (Wordbank, 2020). For example, in 1960, while the fertility rate in Turkey was 6.36 , the fertility rate in the world was 4.98 and by 2018 , the fertility rate had fallen in both Turkey and the world by 2.06 and 2.41 , respectively. The decrease in fertility rate coupled with an increase in life expectations has caused aging of the population. With this drop-in birth rate, young population has entered a downward trend and the share of the elderly population has increased in the total population (Coile, Diamond, Gruber and Jousten, 2002). According to data from the World Bank between the years 1960 and 2018, increased life expectancy and birth rates were observed in Turkey and across the world (Word bank, 2020). The ratio of life expectancy in the world for the year 1960 was 52.57, and in Turkey, it was 45.36. However, for 2018, the ratios were 72.56 and 77.43, respectively (World Bank, 2020). 
According to the Turkish Statistical Institute (TSI), the share of the population in Turkey aged 65 and above of the total population has increased from a rate of $8 \%$ in 2014 to $8.8 \%$ in 2018 (TSI, 2019). This rate was $9.1 \%$ in the world (World Bank, 2018). The top three countries with the highest elderly population ratio were Monaco with $33.2 \%$, Japan, with $28.4 \%$, and Germany with $22.4 \%$. Turkey was ranked 66 among 167 countries. As claimed by Coulmas (2007), societies are divided into three categories according to the rate of the elderly of the total population. An aging society is if the elderly population is between $7 \%-13 \%$, an aged society is if the elderly population is between $14 \%-20 \%$, and a hyper-aged society is if the elderly population is $21 \%$ or more. According to the results from the World Bank (2020), Turkey is still an aging society.

Additionally, the rate of old dependency, which refers to the number of elderly per hundred people at working age, increased from $11.8 \%$ in 2014 to $12.9 \%$ in 2018 . With a different perspective, the number of the elderly is not only increasing but also are also gaining an improvement in their healthy living quality. Actually, the increase in the share of the elderly in employment can be interpreted that they can work and therefore, they are healthy. The term "compression of morbidity" by demographers and healthcare professionals also increases the length of healthy old age (Bloom, Canning and Fink 2011). The compression of morbidity means that an important portion of a country's population can continue to work if they wish and if their health condition allows. According to the Turkish Statistical Institute, there were 6.1 million people, who were 65 years old and above in the workforce age group in 2014 and when compared to the last 5 years, this number increased by 21.9 percent and rose to 7.5 million people (TSI, 2019). By working longer, people can save for their retirement more than in the past.

This study aims to investigate the relationship between population aging and economic growth in Turkey over the period of 1970-2018 conducting a time-series analysis. For this purpose, we included domestic savings, consumption expenditures, and financial development in growth specification as additional variables. Ng-Perron unit root tests were employed to detect the stationarity properties of variables. The Johansen procedure and Autoregressive Distributed Lag Bound Test (ARDL) bounds test to cointegration were employed to determine the long-run relationship among the variables. We estimated the long-run coefficients by applying the Dynamic Ordinary Least Square (DOLS) and Canonical Cointegrating Regression (CCR) estimators. Finally, to examine the causal linkages among the variables, the Vector Error Correction Model (VECM) procedure was used. This study assumed that population aging is negatively related to economic growth and population aging and economic growth cause each other in the long-run. Therefore, the study can provide important policy suggestions for the Turkish economy, at the same time 
because there is not much work about this topic for turkey, our study is expected to contribute to the literature.

The remainder of this paper is organized as follows. Section 1 explains the literature review. Section 2 reviews Turkey's population and economic growth profile. Section 3 describes the data and empirical models used in this study. Section 4 and 5 discuss the methodology and empirical findings. Then, provides a conclusion and policy implication.

\section{LITERATURE REVIEW}

How does population aging affect economic growth and development? This has been a question that has been explained by economists, population scientists, and politicians with different aspects. There is an unprecedented process for the aging of the population worldwide. There is no consensus in the literature about the effects of population aging on economic performance. Most researchers argue that population aging has a negative effect on economic growth while some argue that a positive interaction exists between aging and growth. Moreover, other researchers maintain mixed results or insignificant effects from their studies.

One of the studies that provide a negative relationship is from Lindh and Malmberg (1999). The authors examine for OECD countries and provide the result that workers aged 65 and above has a negative impact on output. With regard to Bloom, Canning and Finlay (2010) they use 1960 - 2005 data to investigate the influence of demographic transition on economic growth in Asia. Their results bring to light that the old-age dependency ratio has an insignificantly reducing impact on economic growth. They took into account the behavioral responses that have the opportunity to change the age structure. For example, the drop-in birth rates leads an increase in female labor force participation, with the increase in life expectancy the change of the saving instincts (elderly tend to save), and enhance in education. They claim that the effect of aging on economic growth will be ambiguous due to various behavioral responses that may impose economic growth effects to different sizes across countries. In a study by Choudhry and Elhorst (2010) covering the period 19612003 for 70 countries, the relationship between demographic indicators and economic growth was examined with the expanded Solow-Swan model. They concluded that the elderly dependency ratio negatively affected the GDP. At the same time, they anticipate that China will face more problems in the coming periods due to the aging population. Park and Shin (2011) examined the effects of demographic change on the economic growth of 12 developing Asian countries from 1981 to 2007 using regression analysis and taken the elderly dependency rate as an indicator of aging; They concluded that it affects growth through savings, capital accumulation, labor force participation and total factor productivity. Their results show that aging has a negative effect on growth. Aksoy, Basso, Smith, and Grasl (2015) found that young and old dependents 
have a negative effect whereas workers contribute positively. They concluded for 21 Organization for Economic Co-operation and Development (OECD) countries that population aging, and reduced fertility have a reducing effect on economic growth and real interest rates. Another study that showed a negative relationship between aging and economic growth was conducted by İsmail, Rahman, Hamidi, and Said (2016) in Malaysia between 1980 and 2011. The authors of this article took the old dependency ratio, life expectancy, and fertility rate as indicators. Population aging rises with increasing life expectancy and declining fertility rate. Maestas, Mullen, and Powell (2016), predicted the magnitude of population aging at the state-level given the USA's age structure, use labor force, and productivity growth to estimate the impact of population aging on Gross Domestic Product (GDP) growth. The paper covered 1980 to 2010 and it revealed that due to the aging population, labor force and productivity growth will decrease and therefore the GDP will decrease. In a study by Lee and Shin (2019), the nonlinear relationship between aging and economic growth in 142 countries was tested and their results indicated that specially developed countries face a serious aging population. With this aging, the proportion of the working population in the total population will decrease and thus GDP will decrease. In the literature, studies on the relationship between population aging and economic growth use the lifetime income hypothesis when investigating the impact of the change in age structure on economic growth. For example, Hsu and Lo (2019) differentiated between the young, prime, and old age populations according to Life-Cycle Hypothesis (LCH). Their study focused on the effect of population aging on aggregate saving, capital formation, and economic growth. Their results suggested that the ongoing aging process is expected to affect the economy negatively.

Some authors such as Fougere and Merette (1999), Ihori, Kato, Kawade and Besshocovers (2005), Cervallati and Sunde (2009), Uddin, Alam and Gow (2016), Acemoglu and Restrepo (2017), Huang, Lin and Lee (2019) demonstrate a positive effect between aging and economic growth. According to Fougere and Merette (1999), their results for seven OECD countries suggest that population aging could create more opportunities for future generations to invest in human capital formation, which would encourage economic growth and reduce significantly the apprehended negative impact of aging on output per capita. In 2005, according to a study done by Ihori et al. (2005) the period between 1965 to 2000 years in Japan, the population over 70 was four times higher than the other age groups. The fast-aging population in Japan has led to a steady increase in national medical spending through existing public health insurance and a pay-asyou-go pension plan. Older people demand more expensive medical equipment and more materials than individuals in other age groups. Thus, the authors came to the conclusion that the aging population will increase economic growth through health expenditure. In a similar study, Ecevit et al. (2018) concluded that an increase in the population aged 65 years or over in Turkich Republics 
will be accompanied by an increase in health expenditures. In the study conducted for Australia by Uddin et al. (2016) they applied three different econometric techniques to examine the relationship between dependency rate, saving rate, and real GDP. These techniques are the dynamic ordinary squares (DOLS), fully modified unusual squares (FMOLS), and vector error correction model (VECM). Each of the models reveals a long-term relationship between variables. Cervallati and Sunde (2009) investigated the causal effect of life expectancy on economic growth by calculating the role of demographic transition. Their research presented that improvements in life expectancy reduce population growth and encourage human capital accumulation after the beginning of demographic transition. Additionally, an adequately high life expectancy is the trigger of the transition to sustained income growth. The study conducted by Acemoglu and Restrepo in 2017, argues that aging will not have a negative effect on economic growth linked to the technological developments that replaced the labor force. Huang et al. (2019) empirical results for Taiwan showed that the aging workforce effect economic growth positively. On the other hand, the old-age dependency effects the economic growth negatively. Additionally, he found that human capital is obligatory for total factor productivity growth and that workforce and population aging mostly affect productivity through Total Factor Productivity (TFP).

Table 1. Studies Addressing the Relationship Between the Aging Population and Economic Performance

\begin{tabular}{|c|c|c|c|c|c|}
\hline Author(s) & $\begin{array}{l}\text { Country/ } \\
\text { Region } \\
\end{array}$ & Period & Methodology & $\begin{array}{l}\text { Independent Variables/Population } \\
\text { structure }\end{array}$ & Con. \\
\hline $\begin{array}{l}\text { Fougere and } \\
\text { Merette } \\
\text { (1999) }\end{array}$ & $\begin{array}{l}\text { Seven } \\
\text { OECD } \\
\text { countries }\end{array}$ & $\begin{array}{l}1954- \\
2050\end{array}$ & OLG & $\begin{array}{l}\text { Human capital, physical capital, } \\
\text { final goods sector, cohort } \\
\text { behavior, government behavior. }\end{array}$ & + \\
\hline $\begin{array}{l}\text { Lindh and } \\
\text { Malmberg } \\
(1999)\end{array}$ & $\begin{array}{l}\text { OECD } \\
\text { countries }\end{array}$ & $\begin{array}{l}1950- \\
1990\end{array}$ & $\begin{array}{l}\text { Pooled and } \\
\text { panel } \\
\text { estimations }\end{array}$ & $\begin{array}{l}\text { Human capital, physical capital, } \\
\text { savings rate, investment share, } \\
\text { workforce growth, technology, } \\
\text { age groups. }\end{array}$ & - \\
\hline $\begin{array}{l}\text { Ihori et al. } \\
\text { (2005) }\end{array}$ & Japan & $\begin{array}{l}1965- \\
2000\end{array}$ & OLG & $\begin{array}{l}\text { Demography, government } \\
\text { deficits, social security system, } \\
\text { public pension scheme, public } \\
\text { health insurance, taxes, } \\
\text { technological progress. }\end{array}$ & + \\
\hline $\begin{array}{l}\text { Cervallati } \\
\text { and Sunde } \\
(2009) \\
\end{array}$ & $\begin{array}{l}47 \\
\text { Countries }\end{array}$ & $\begin{array}{l}1940- \\
2000\end{array}$ & OLS & $\begin{array}{l}\text { Human capital, fertility rate, } \\
\text { mortality rate, life expectancy. }\end{array}$ & + \\
\hline $\begin{array}{l}\text { Bloom et al. } \\
(2010)\end{array}$ & $\begin{array}{l}\text { Asian } \\
\text { Countries }\end{array}$ & $\begin{array}{l}1960- \\
2005\end{array}$ & OLS & $\begin{array}{l}\text { Behavioral change, fertility rate, } \\
\text { life expectancy, age distribution. }\end{array}$ & - \\
\hline $\begin{array}{l}\text { Choudhry } \\
\text { and Elhorst } \\
\text { (2010) }\end{array}$ & $\begin{array}{l}70 \\
\text { Countries }\end{array}$ & $\begin{array}{l}1961- \\
2003\end{array}$ & $\begin{array}{l}\text { Augmented } \\
\text { Solow-Swan } \\
\text { model }\end{array}$ & $\begin{array}{l}\text { Working-age, total population, } \\
\text { child -old-age dependency ratios. }\end{array}$ & - \\
\hline
\end{tabular}


Table 1 continued...

\begin{tabular}{|c|c|c|c|c|c|}
\hline Author(s) & $\begin{array}{l}\text { Country/ } \\
\text { Region }\end{array}$ & Period & Methodology & $\begin{array}{l}\text { Independent } \\
\text { Variables/Population } \\
\text { structure }\end{array}$ & Con. \\
\hline $\begin{array}{l}\text { Park and } \\
\text { Shin } \\
(2011)\end{array}$ & $\begin{array}{l}12 \\
\text { developing } \\
\text { Asian } \\
\text { Countries }\end{array}$ & 1981-2007 & $\begin{array}{l}\text { Regression } \\
\text { analysis }\end{array}$ & $\begin{array}{l}\text { The } \\
\text { dependency - old dependency } \\
\text { ratio, total factor } \\
\text { productivity, labor force } \\
\text { participation, the capital } \\
\text { accumulation, the savings } \\
\text { rate, GDP. }\end{array}$ & - \\
\hline $\begin{array}{l}\text { Aksoy et } \\
\text { al. (2015) }\end{array}$ & $\begin{array}{l}21 \text { OECD } \\
\text { countries }\end{array}$ & $1970-2007$ & Panel VAR & $\begin{array}{l}\text { Investment, savings, interest } \\
\text { rates, CPI, per-capita real } \\
\text { GDP. }\end{array}$ & - \\
\hline $\begin{array}{l}\text { Ismail et } \\
\text { al.(2016) }\end{array}$ & Malaysian & $1980-2011$ & $\begin{array}{l}\text { Autoregressive } \\
\text { Distributed Lag } \\
\text { (ARDL) }\end{array}$ & $\begin{array}{l}\text { Government expenditure, } \\
\text { domestic savings, human } \\
\text { capital, fertility rate, per } \\
\text { capita real GDP. }\end{array}$ & - \\
\hline $\begin{array}{l}\text { Uddin et } \\
\text { al. }(2016)\end{array}$ & Australia & 1971-2014 & $\begin{array}{l}\text { DOLS, } \\
\text { FMOLS, } \\
\text { VECM, } \\
\text { Granger } \\
\text { Causality }\end{array}$ & $\begin{array}{l}\text { Per capita real GDP, saving } \\
\text { rate, dependency ratio. }\end{array}$ & + \\
\hline $\begin{array}{l}\text { Maestas, } \\
\text { Mullen, } \\
\text { and } \\
\text { Powell } \\
(2016)\end{array}$ & $\begin{array}{l}\text { United } \\
\text { States }\end{array}$ & $1980-2010$ & OLS & $\begin{array}{l}\text { labor force and productivity } \\
\text { growth, Population aged } \\
60+, \text { per capita real GDP. }\end{array}$ & - \\
\hline $\begin{array}{l}\text { Acemoglu } \\
\text { and } \\
\text { Restrepo } \\
(2017)\end{array}$ & $\begin{array}{l}169 \\
\text { countries }\end{array}$ & $1965-2015$ & OLS & $\begin{array}{l}\text { Physical capita, labor force, } \\
50+\text { and } 20-49 \text { years group, } \\
\text { productivity of older } \\
\text { worker, domestic } \\
\text { technology, GDP. }\end{array}$ & + \\
\hline $\begin{array}{l}\text { Lee and } \\
\text { Shin } \\
(2019)\end{array}$ & $\begin{array}{l}142 \\
\text { countries }\end{array}$ & $1960-2014$ & Panel data & $\begin{array}{l}\text { Old-age population share, } \\
\text { young age population share, } \\
\text { working age share, physical } \\
\text { capital, labor force, } \\
\text { productivity level, (GDP). }\end{array}$ & - \\
\hline $\begin{array}{l}\text { Huang et } \\
\text { al. (2019) }\end{array}$ & Taiwan & 1981-2017 & OLS & $\begin{array}{l}\text { GDP per worker, old-age } \\
\text { dependency ratio, aging } \\
\text { workforce, eldercare } \\
\text { workforce, youth } \\
\text { dependency ratio, } \\
\text { employment rate, workforce } \\
\text { with college or higher } \\
\text { educational attainment, } \\
\text { investment rate. }\end{array}$ & $+/-$ \\
\hline $\begin{array}{l}\text { Hsu and } \\
\text { Lo (2019) }\end{array}$ & Japan & $2016-2065$ & $\mathrm{LCH}$ & $\begin{array}{l}\text { GDP growth, saving, } \\
\text { physical capital. }\end{array}$ & - \\
\hline
\end{tabular}

Source: The table were created by the authors. 


\section{PROFILE \\ 2. TURKEY'S POPULATION AND ECONOMIC GROWTH}

Towards the end of the $20^{\text {th }}$ century, due to an increased share of women in employment and the tendency of families to have fewer children, birth rates decreased dramatically. In addition to these changes, we can also refer that technological improvement, recovery in the living conditions, a decrease in mortality rates and an increased in life expectancy in the world. For these reasons, the proportion of the young population in the total population (\%) decreased and the proportion of the elderly population increased.

Table 2. Population Aged 65 and Above (\% of the total population) for Selected Countries.

\begin{tabular}{lccc}
\hline \multicolumn{1}{c}{ Countries } & \multicolumn{3}{c}{ Population Aged 65 and Above (\% of the total population) } \\
& Aging society $\%$ & Aged society \% 14 & Hyper-Aged \%20 \\
\hline Turkey & 2009 & 2040 & 2060 \\
Taiwan & 1993 & 2018 & 2026 \\
\hline Japan & 1971 & 1995 & 2005 \\
\hline South Korea & 1999 & 2017 & 2026 \\
\hline Singapore & 2004 & 2018 & 2026 \\
\hline China & 2002 & 2025 & 2035 \\
\hline France & 1864 & 1990 & 2019 \\
\hline Germany & 1932 & 1972 & 2008 \\
\hline United Kingdom & 1929 & 1975 & 2026 \\
\hline United States & 1942 & 2014 & 2029 \\
\hline Canada & 1945 & 2010 & 2024 \\
\hline
\end{tabular}

Source: World Bank, 2020 and Huang et al. 2019.

As seen from table 2, although Turkey entered aging society late compared to other countries and has not yet reached other stages, the population of 65 years and above has been increasing in Turkey over the years. The rise in the population of 65 years and older can be seen clearly in Figure 1. Also, we see that the 0-14 age group has decreased over the years. 
Figure 1. Population Aged 15-64, Population ages 0-14 and Population ages 65 and above (\% of the total population), 1960-2018.

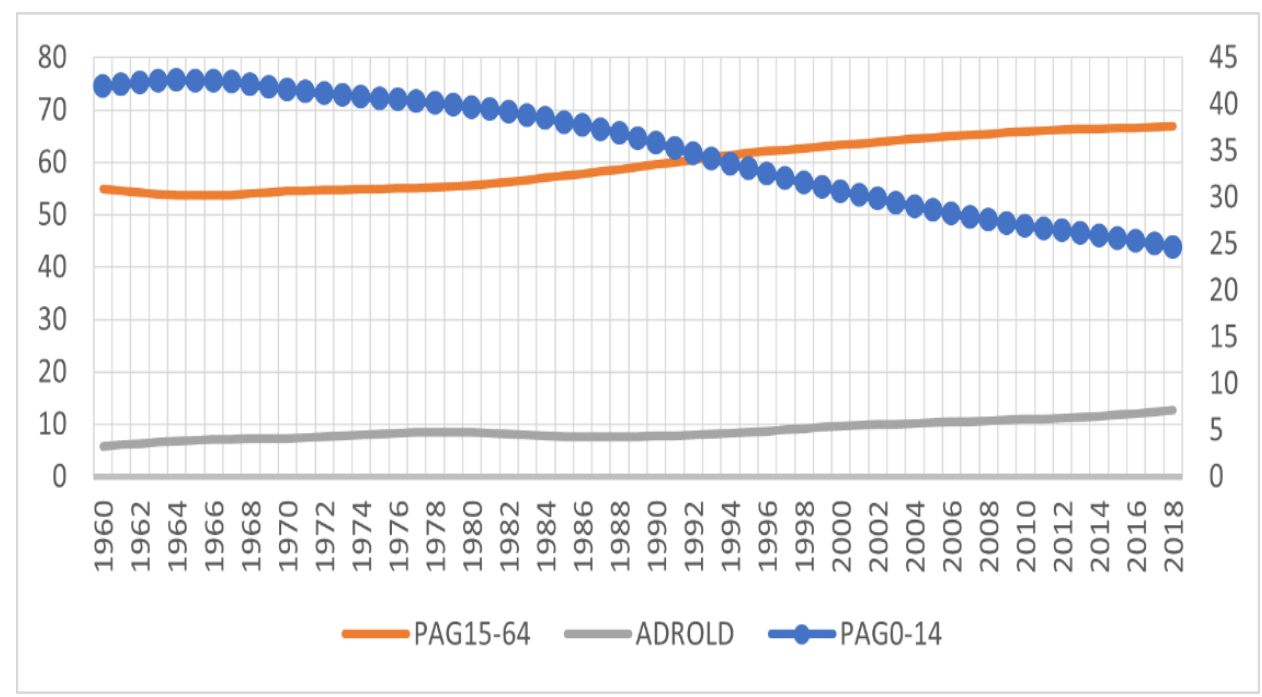

Source: Data on age structures was collected from the World Bank's (World Development Indicators) online database, 2020, and graphed by the authors.

Recently, according to the Turkey Statistical Institute, the birth rate per woman and the infant mortality rate decreased; thus, life expectancy has increased. This change has led to the deterioration of the age structure of the world as well as in Turkey. In addition, the young dependency ratio is called the ratio of the population between the ages of $0-14$ and the population between the ages of 15-64. With the decrease in the fertility rate, the share of the population between the ages of 0-14 in the total population tends to decrease, resulting in an increase in the elderly dependency rate. Therefore, the increase in the population aged 65 and above causes an increase in the elderly dependency ratio (Günsoy and Tekeli, 2015). Figure 2 shows the comparison of age dependency ratio (which is the young and old dependency ratio) \% of the total population. 
Figure 2. The comparison of Age Dependency Ratio (Young and old Dependency Ratio) \% of Total Population, 1960-2018

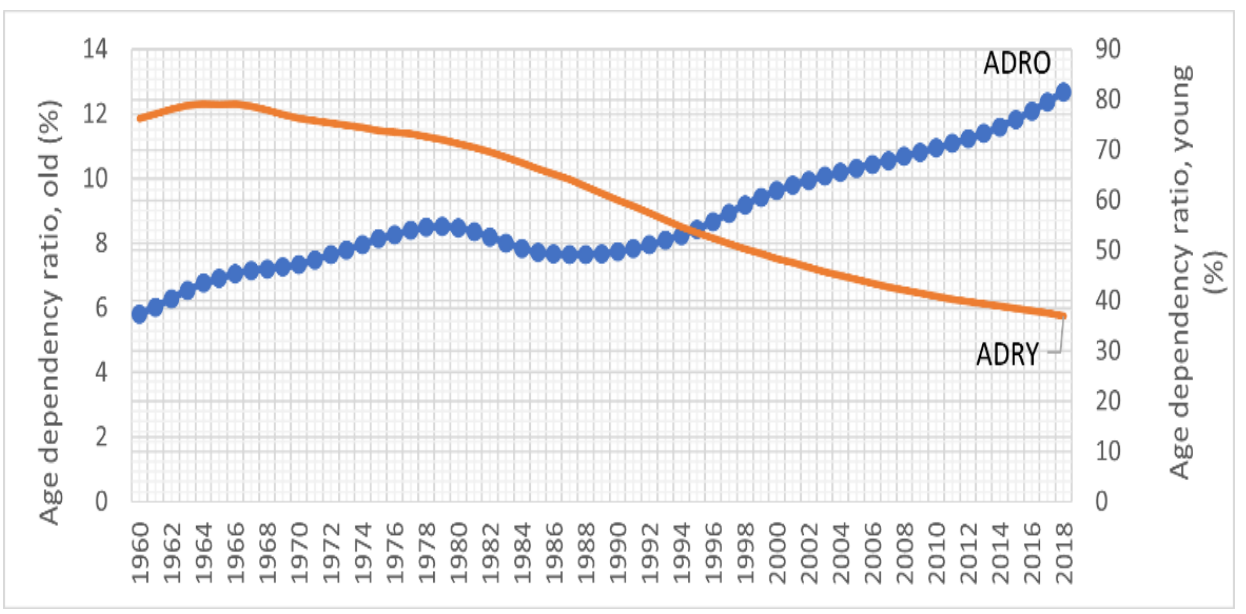

Source: Data was taken from the World Databank, 2020 and graphed by the authors ADRY; Age Dependency Ratio, Young (\% of Total Population), ADRO: Age Dependency Ratio, Old (\% of Total population).

Between 1960 and 2018, while the old dependency rate has increasing continuously, the young dependency rate has showed a downward trend. While the old dependency ratio for the year 1980 was $8.47 \%$, this ratio was $7.83 \%$ in 1991. After these years, the old dependency ratio has increased steadily. For example, while this ratio was $12.08 \%$ in 2016 , the ratio reached $12.68 \%$ in 2018. The young dependency ratio has decreased since 1967 and while this ratio was $38.00 \%$ in 2016, the ratio reached $36.86 \%$ in 2018. According to the Turkish Statistical Institute Address Based Population Registration System (ABPRS) results in 2017, new population projections were produced according to three separate scenarios, including different fertility rates and migration assumptions. As seen in Figure 3 and Figure 4, life expectancy at birth increased in Turkey and the population continued to age. Median age, which is an important indicator of the age structure of a population, was $32 \%$ in 2018 and is expected to be $33.5 \%$ in $2023,38.5 \%$ in $2040,42.3 \%$ in 2060 , and $45 \%$ in 2080 . 
Figure 3. Population of Selected Age Groups by Scenarios, 2018, 2023, 2040, 2060, and 2080



Source: Data was taken from TurkStat, Population Projections, 2018-2080 and graphed by the authors.

The main scenario is the basic scenario, which is used for population projections. The high scenario is based on higher assumptions for fertility and net international migration than the main scenario, while the low scenario has lower fertility and net international migration assumptions. As the ratios were calculated by the unrounded figures, they may differ from the ratios to be calculated by the figures given in the graph.The proportion of the population aged 65 and over, defined as the elderly population, is projected to be $10.2 \%$ in $2023,16.3 \%$ in $2040,22.6 \%$ in 2060 , and $25.6 \%$ in 2080 . Population in the group of 15-64 working age groups was $67.8 \%$ in 2018 and is expected to be $67.2 \%$ in $2023,64.4 \%$ in $2040,60.4 \%$ in 2060 , and $58.7 \%$ in 2080 . The proportion of the population in the $0-14$ age group, defined as child population, was $23.5 \%$ in 2018 and is predicted to be $22.6 \%$ in $2023,19.3 \%$ in $2040,16.9 \%$ in 2060 , and $15 \%$ in 2080 . 
Figure 4. Population Growth Rate (annual \%) and Life Expectancy at Birth, Total (years)

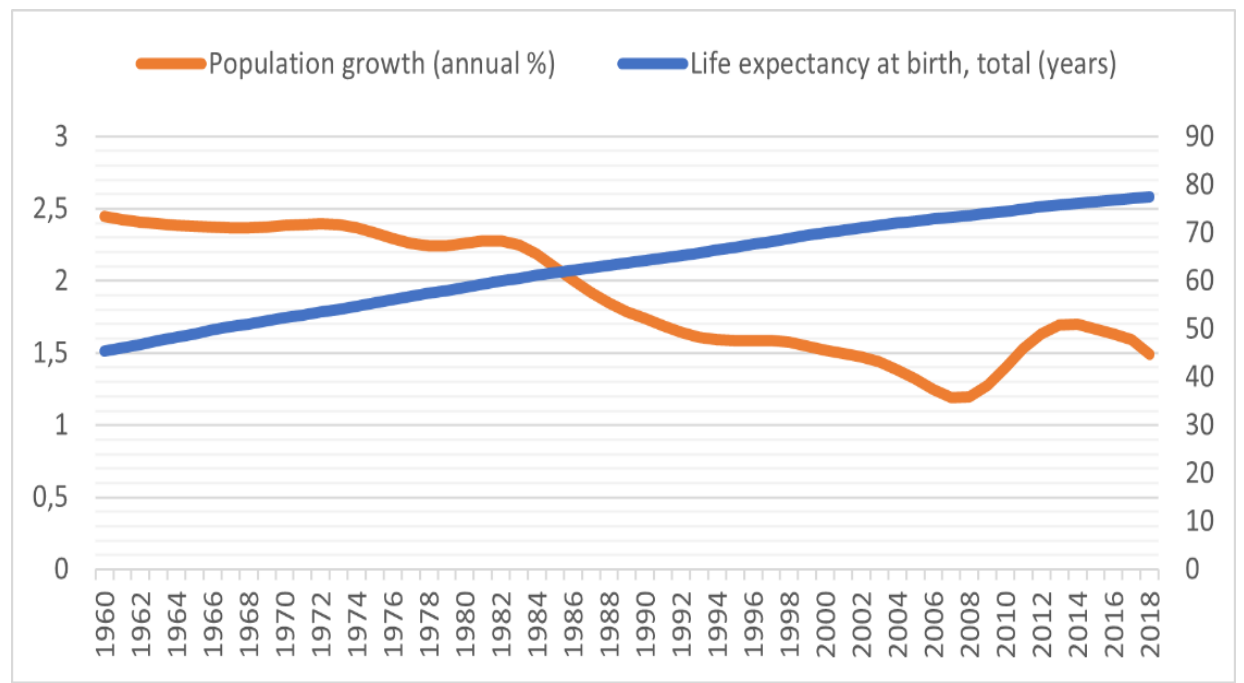

Source: Data was taken from the World Databank, 2020 and graphed by the authors.

Many indicators can be considered to reveal the change in the population structure of any country. For example, the change in the population structure is in the fertility rate, birth and death rates, life expectancy, elderly, young, total dependency rates, and retirement age, etc., which cause changes to take place. While the change in the demographic structure of the population primarily causes the age structure of the population to change, it also affects many economic areas. In many theoretical and empirical studies that examine the relationship between population growth and economic growth, it is stated that population growth is a factor that hinders economic growth and development, and population growth has different benefits depending on the conditions of the countries. 
Figure 5. The Impact of Aged Dependency Ratio (\%) on Gross Domestic Saving (\%) and Gross National Expenditure (\%).

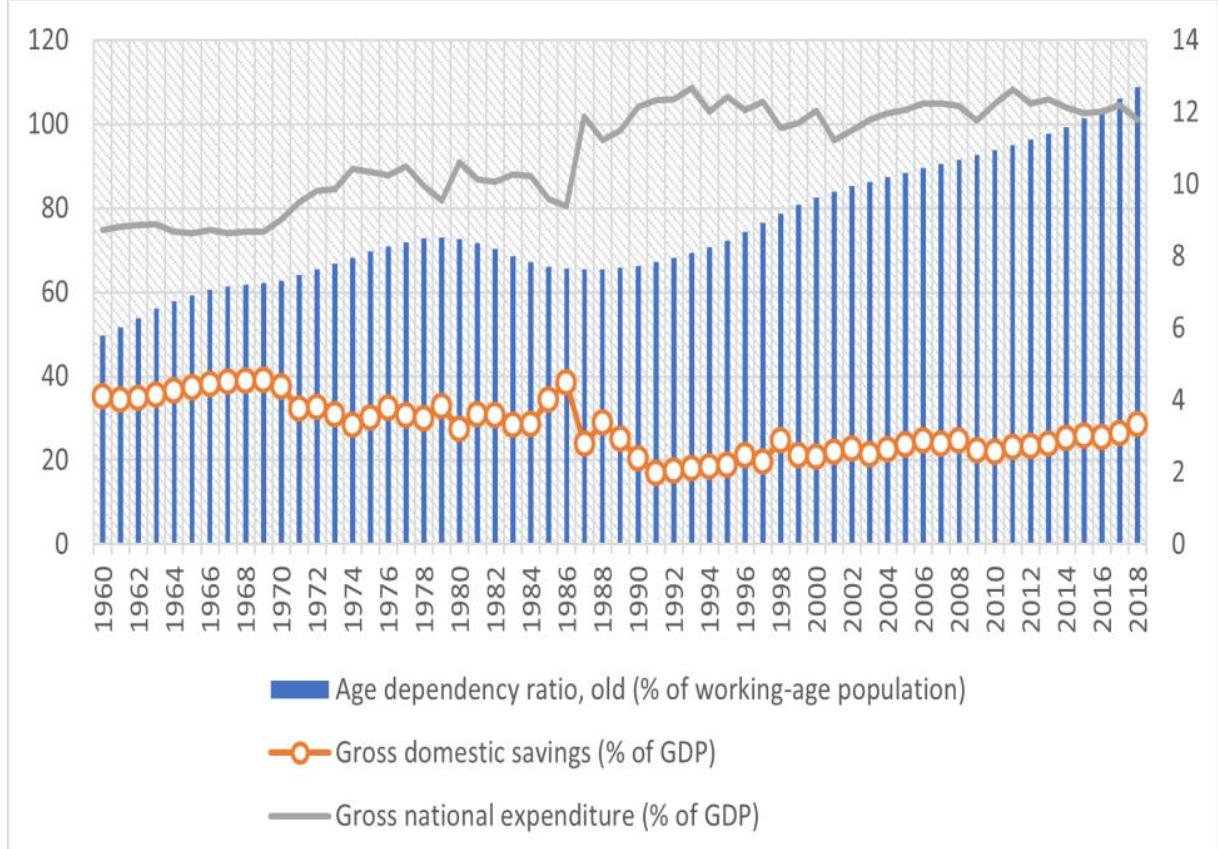

Source: Data on age structures were collected from the World Bank's World Development Indicators online database, 2020, and graphed by the authors.

As figure 5 is analyzed, while the share of the old-age dependency ratio (\%of working-age population) was $5.81 \%$ in 1960 , this rate was $12.68 \%$ in 2018 . There has been an increase of $6.87 \%$ in 58 years. It can be said that all three variables in the chart have the same correlation. Also, as can be seen from the figure, we see that as the population over 65 increases, savings and consumption expenditures also increase. From this graph, it can be concluded that aging affects both saving and consumption tendencies of individuals according to the development levels of the countries in question and for various reasons. It is a fact that in almost every country, the elderly population is more dominant than other age groups or will be in the future. By increasing the labor force participation rate of the elderly, the potential workforce capacity of the countries can be contributed, and thus a gain can be made instead of loss of income. 


\section{DATA SET AND MODEL}

The study was built on the foundation of the studies by Kinugasa and Mason (2007), Choudhry and Elhorst (2010), Uddin et al. (2016), Ismail et al. (2016), and Zhao, Xu, Zhang and Xia (2018). Following these authors, we used the following log-linear model to investigate the impact of population aging on economic growth in Turkey:

$$
\ln G D P_{t}=\beta_{0}+\beta_{1} \ln A G I N G_{t}+\beta_{2} \ln S A V_{t}+\beta_{3} \ln C O N S_{t}+\beta_{4} \ln F I N_{t}+\varepsilon_{t}
$$

The dependent variable is real GDP per capita as a measure of economic growth (Eren, Taspinar and Gokmenoglu (2019). Independent variables are the share of the elderly population in the total population as an indicator of population aging (Zhao et al., 2018),government consumption expenditure (Landau, 1983), domestic savings (Caceres, 1995), and broad money supply as a measure of financial development (Adua, Marbuah and Mensah 2013). The sign of $\beta_{1}$ is expected to be negative because population aging decreases economic growth (Kinugasa and Mason, 2007). Domestic savings is positively related to economic growth; therefore, it is expected that the sign of $\beta_{2}$ will be positive (Aghion, Comin, Howitt and Tecu, 2009). Consumption expenditure can lead to an increase in economic growth. Thus, the sign of $\beta_{3}$ is expected to be positive (Bailey, 1971). Financial development can affect economic growth positively or negatively. Therefore, the expected sign of $\beta_{4}$ can be positive or negative (Shaw, 1973; Devereux and Smith, 1994). All the variables were transformed to a natural logarithm. The study used annual data for 1970-2018. All the data was obtained from the World Bank, World Development Indicators Database (2020). The detailed definition of variables is reported in Table 3. It is possible to see the general trends of the series included in the analysis for 1970-2018 in Figure 6. The detailed definitions of the variables are shown in Table 3. Figure 6. shows the plots of the series used in the study.

Table 3. Definition of the variables

\begin{tabular}{|l|l|l|}
\hline Variables & Definition & Source \\
\hline $\operatorname{lnGDP}$ & Real GDP per capita (constant 2010 USD) & WDI \\
\hline $\ln$ AGING & Age dependency ratio, old $(\%$ of working-age population) & WDI \\
\hline $\operatorname{lnSAV}$ & Gross domestic savings (\% of GDP) & WDI \\
\hline $\ln C O N S$ & Government final consumption expenditures $(\%$ of GDP) & WDI \\
\hline $\ln F I N$ & Broad money $(\%$ of GDP) & WDI \\
\hline
\end{tabular}


Figure 6. Plots of the series employed in the study (1970-2018)
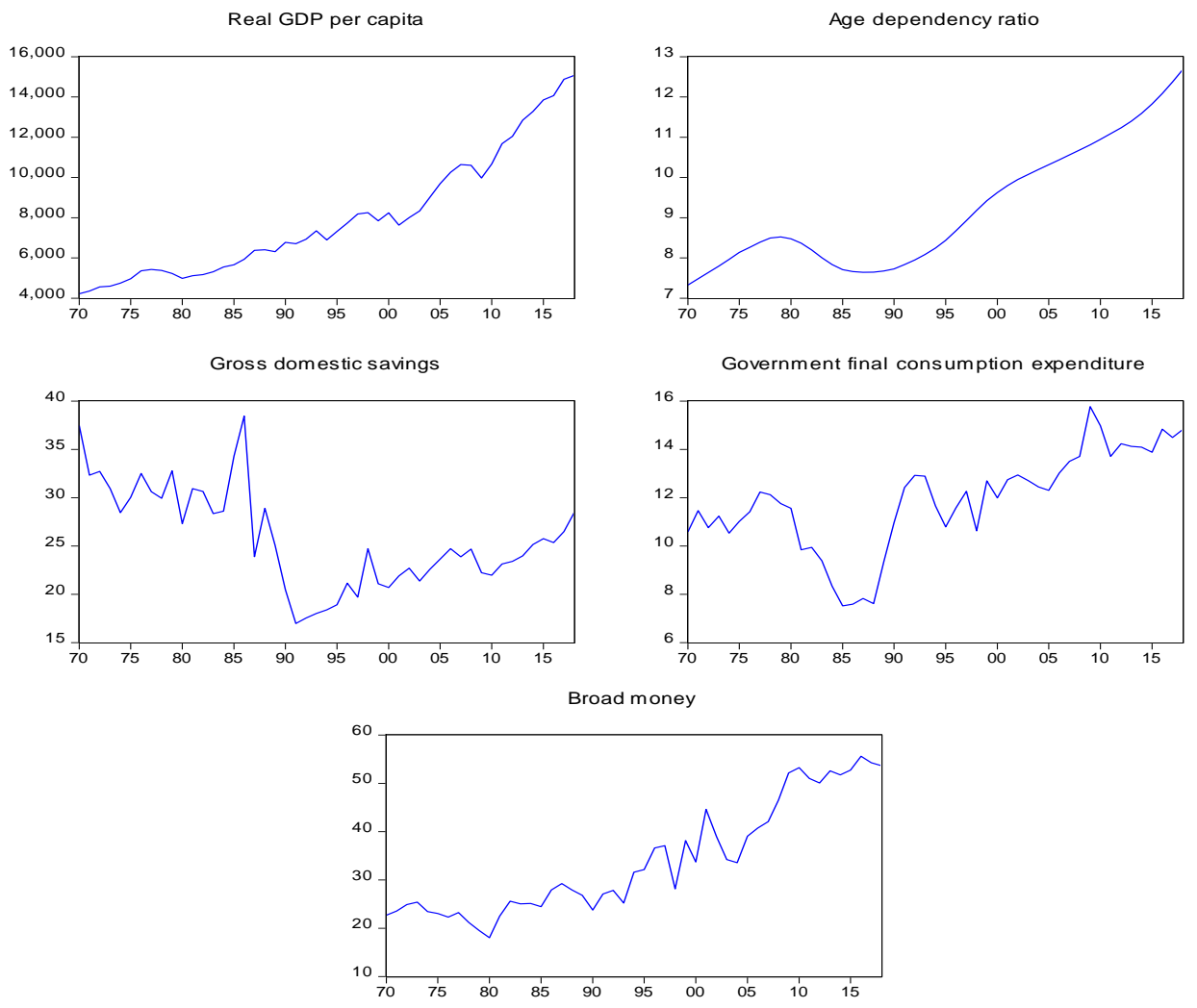

\section{METHODOLOGY}

We followed a three-step procedure for the empirical methodology. The first step was to examine the stationarity of the variables through the $\mathrm{Ng}$-Perron unit root test. Compared to the classical unit root tests such as the ADF and DF, the Ng-Perron unit root test possesses good size and explanatory power. In addition, this test is suitable for small samples (Shahbaz, Afza, Shabbir (2011). $\mathrm{Ng}$ and Perron (2001) modified the test statistics, such as $\mathrm{MZ}_{\mathrm{a}}, \mathrm{MZ}_{\mathrm{t}}, \mathrm{MSB}$, and MPT presented by Phillips and Perron (1988), Bhargava (1986), and Elliott, Rothenberg and Stock (1996). The Ng-Perron test statistics can be specified as follows:

$$
\begin{aligned}
& M Z_{\alpha}=\left(\left(T^{1} y_{T}^{d}\right)^{2}-f_{0}\right) / 2 k \\
& M Z_{t}=M Z_{\alpha} x M S B \\
& M S B=\left(k / f_{0}\right)^{1 / 2} \\
& M P T=\left(\bar{c}^{2} k-\bar{c} T^{1}\right)\left(y^{d} T\right)^{2} / f_{0}
\end{aligned}
$$


It was concluded that the variable is stationary when the test statistic is larger than the critical value developed by $\mathrm{Ng}$ and Perron (2001).

In the second step, the ARDL approach was applied to investigate the cointegration between the variables. The ARDL procedure allowed us to consider the $I(0)$ or $I$ (1) variables together. This approach investigates the existence of a level relationship between the variables. It provides efficient results for small sample size (Cetin et al., 2018). The UECM, which is an important part of the ARDL model, leads us to analyze both the long-run and short-run parameters (Pesaran, Shin and Smith 2001). The UECM can be expressed as follows:

$$
\begin{gathered}
\Delta \ln G D P_{t}=\alpha_{0}+\sum_{\substack{i=1 \\
q}}^{p} \alpha_{1 i} \Delta \ln G D P_{t-i}+\sum_{i=0}^{q} \alpha_{2 i} \Delta \ln A G I N G_{t-i} \\
+\sum_{i=0}^{q} \alpha_{3 i} \Delta L N S A V_{t-i}+\sum_{i=0}^{q} \alpha_{4 i} \Delta \ln C O N S_{t-i} \\
+\sum_{i=0}^{q} \alpha_{4 i} \Delta \ln F I N_{t-i}+\beta_{1} L N G D P_{t-1}+\beta_{2} \ln A G I N G_{t-1}+\beta_{3} L N S A V_{t-1} \\
+\beta_{4} \ln C O N S_{t-1}+\beta_{4} \ln F I N_{t-1}+u_{t}(6)
\end{gathered}
$$

where $\Delta$ is the first different operator, $\alpha_{0}$ is the drift component, and $u_{t}$ is the error term. We used the AIC or SIC criteria to determine the appropriate lag length. In this procedure, the null hypothesis, $H_{0}: \beta_{1}=\beta_{2}=\beta_{3}=\beta_{4}=\beta_{5}=0$ is tested against the alternative hypothesis, which is $H_{1}: \beta_{1} \neq \beta_{2} \neq \beta_{3} \neq \beta_{4} \neq$ $\beta_{5} \neq 0$. The upper and lower critical bounds (UCB and LCB) suggested by Pesaran et al. (2001) were compared with the $F$-statistic to determine the existence of cointegration. Cointegration exists when the $F$-statistic is larger than the UCB. Cointegration does not exist when the $F$-statistic is lower than the LCB. If the $F$-statistic is between these critical bounds, the finding is conclusive. To determine the reliability of the ARDL model, we applied several diagnostic tests to investigate the existence of serial correlation, normality, functional form, and heteroscedasticity. We also applied stability tests through the cumulative sum of recursive residuals (CUSUM) and the cumulative sum of squares of recursive residuals (CUSUMSQ).

In this study, to check the robustness of the cointegration findings we also applied the multivariate cointegration approach developed by Johansen (1988), considering the maximum likelihood procedure. He presented two test statistics for determining the number of cointegrated vectors. These are the trace and maximum eigenvalue statistics and can be expressed as follows: 


$$
\begin{aligned}
& \lambda_{\text {trace }}=-T \sum_{i=r+1}^{p} \ln \left(1-\hat{\lambda}_{i}\right) \\
& \lambda_{\text {max }}=-T \ln \left(1-\hat{\lambda}_{r+1}\right)
\end{aligned}
$$

In the above specifications, $T$ and $\hat{\lambda}_{i}$ indicate the sample size and the $i^{\text {th }}$ largest canonical correlation, respectively. The trace test tests the null hypothesis of $\mathrm{r}$ cointegrating vectors against the alternative hypothesis of $\mathrm{n}$ cointegrating vectors. The maximum eigenvalue test, on the other hand, tests the null hypothesis of $r$ cointegrating vectors against the alternative hypothesis of $1+r$ cointegrating vectors. Asymptotic critical values are scheduled in Johansen and Juselius (1994). In the third step, the long-run parameters were estimated using the DOLS and CCR estimators. The DOLS and CCR approaches can be applied when the variables are stationary at their first difference. Stock and Watson (1993) suggested a very dynamic model that considers the first differences of the regressors and leads and lags of the first differences. This procedure eliminates several problems such as the serial correlation and endogeneity of the regressors. The DOLS model can be expressed as follows:

$$
y_{t}=X_{t}^{\prime} \beta+D_{1 t}^{\prime} \sum_{j=-q}^{r} \Delta X_{1+j}^{\prime} \delta+v_{1 t}
$$

where $\mathrm{q}$ shows the numbers of leads or lags. It is argued that DOLS can provide more robust findings than the OLS and FMOLS estimators in finite samples (Mitic et al., 2017). The DOLS has the same asymptotic distribution as those obtained from FMOLS and CCR (Mehmood and Shahid, 2014). The CCR, a nonparametric procedure, is based on a transformation of the variables in the cointegrating regression that removes the second-order bias of the OLS estimator in the general case. The transformed series can be expressed as follows:

$$
\begin{aligned}
& y_{2 t}^{*}=y_{2 t}-\left(\Sigma^{-1} \wedge_{2}\right)^{\prime} u_{t} \\
& y_{1 t}^{*}=y_{1 t}-\left(\Sigma^{-1} \wedge_{2} \beta+\left(0, \Omega_{12} \Omega_{22}^{-1}\right)^{\prime}\right)^{\prime} u_{t}
\end{aligned}
$$

The canonical cointegration regression can be expressed as follows:

$$
y_{1 t}^{*}=\beta^{\prime} y_{2 t}^{*}+u_{1 t}^{*}
$$

where

$$
y_{1 t}^{*}=u_{1 t}-\Omega_{12} \Omega_{22}^{-1} u_{2 t}
$$

The OLS estimator of (11) is asymptotically equivalent to the Maximum Likelihood estimator. Additionally, (12) indicates how the transformation of the 
variables eliminates the asymptotic bias due to the possible cross-correlation between $u_{1 \mathrm{t}}$ and $u_{2 \mathrm{t}}$.

In the last step, we detected the causality among the variables by applying the VECM procedure. Engle and Granger (1987) augmented the classical Granger causality technique by integrating an error-correction term $\left(\mathrm{ECT}_{\mathrm{t}-1}\right)$ into the VAR models as a new variable. This causality procedure requires that the variables are integrated at $I$ (1). When considering our variables, the VECM can be expressed as follows:

$$
\begin{aligned}
(1-L)\left[\begin{array}{c}
\ln G D P_{t} \\
\ln A G I N G_{t} \\
\ln S A V_{t} \\
\ln \operatorname{CONS}_{t} \\
{\ln F I N_{t}}_{t}
\end{array}\right] \\
=\left[\begin{array}{l}
b_{1} \\
b_{2} \\
b_{3} \\
b_{4} \\
b_{5}
\end{array}\right]+\sum_{i=1}^{p}(1-L)\left[\begin{array}{l}
c_{11 i} c_{12 i} c_{13 i} c_{14 i} c_{15 i} \\
c_{21 i} c_{22 i} c_{23 i} c_{24 i} c_{25 i} \\
c_{31 i} c_{32 i} c_{33 i} c_{34 i} c_{35 i} \\
c_{41 i} c_{42 i} c_{43 i} c_{44 i} c_{45 i}
\end{array}\right] x\left[\begin{array}{c}
\ln G D P_{t-1} \\
\ln A G I N G_{t-1} \\
\ln S A V_{t-1} \\
\ln C O N S_{t-1} \\
\ln F I N_{t-1}
\end{array}\right] \\
+\left[\begin{array}{l}
\beta \\
\theta \\
\delta \\
\gamma \\
\vartheta
\end{array}\right] E C T_{t-1}+\left[\begin{array}{l}
u_{1 t} \\
u_{2 t} \\
u_{3 t} \\
u_{4 t} \\
u_{5 t}
\end{array}\right](14)
\end{aligned}
$$

where (1-L) shows the first-difference operator; $\beta, \theta, \delta, \gamma$, and $v$ indicate the parameters of the $E C T_{t-1} ; u_{1}, u_{2}, u_{3}, u_{4}$, and $u_{5}$ denotes the residual terms. The significance of the $t$-statistic of the $E C T_{t-1}$ indicates the long-run causality. This also indicates the presence of cointegration among the variables. In addition, the joint $F$-statistical significance of the first difference lagged independent variables implies short-run causality.

\section{EMPIRICAL FINDINGS}

A summary of the descriptive statistics is reported in Table 4 The mean is larger for per capita real GDP than for the other series. The standard deviation is lower for population aging than for the other series. The median is higher for financial development than for population aging, domestic savings, and consumption expenditures. The value of kurtosis for the variables of per capita real GDP, population aging, domestic savings, consumption expenditures, and financial development is equal to $2.669,2.150,2.550,2.700$, and 1.924, respectively. 
Table 4. Descriptive Statistics (Time series data: 1970-2018)

\begin{tabular}{llllll}
\hline Statistics & GDP & AGING & SAV & CONS & FIN \\
\hline Mean & 7966.689 & 9.211 & 25.777 & 11.859 & 34.075 \\
Median & 7315.404 & 8.491 & 24.718 & 12.124 & 29.238 \\
Std. dev. & 3046.141 & 1.534 & 5.178 & 2.045 & 11.551 \\
Min. & 4221.154 & 7.327 & 16.979 & 7.515 & 18.033 \\
Max. & 15068.98 & 12.686 & 38.450 & 15.770 & 55.604 \\
Skewness & 0.843 & 0.667 & 0.417 & -0.425 & 0.588 \\
Kurtosis & 2.669 & 2.150 & 2.550 & 2.700 & 1.924 \\
Obs. & 49 & 49 & 49 & 49 & 49 \\
\hline
\end{tabular}

Table 5 reports the outcomes from the Ng-Perron unit root test. Our empirical finding indicates that none of the series is stationary at their level but that they are stationary at their first difference. Therefore, the series are integrated at I (1). Therefore, this finding allows us to investigate the presence of the long-run relationship among population aging, savings, consumption expenditures, financial development, and economic growth by employing the ARDL bounds test and Johansen-Juselius cointegration approach during 19702018. The optimal lag length for these cointegration methods was selected as 2 by using the Schwarz Information Criterion (SIC). Table 6 presents the findings.

Table 5. Ng-Perron test results

\begin{tabular}{cccccc}
\hline Variables & MZ $_{\mathrm{a}}$ & $\mathrm{MZ}_{\mathrm{t}}$ & $\mathrm{MSB}$ & $\mathrm{MPT}$ & Result \\
\hline $\ln \mathrm{gDP}$ & -7.297 & -1.789 & 0.245 & 12.697 & - \\
$\ln \mathrm{AGING}$ & -6.570 & -1.724 & 0.262 & 13.901 & - \\
$\operatorname{lnSAV}$ & -8.533 & -1.920 & 0.225 & 11.156 & - \\
$\ln \mathrm{CONS}$ & -6.518 & -1.796 & 0.275 & 13.980 & - \\
$\ln \mathrm{FIN}$ & -0.844 & -0.372 & 0.441 & 14.146 & - \\
\hline$\Delta \operatorname{lnGDP}$ & $-23.489^{* *}$ & $-3.421^{* * *}$ & $0.145^{* *}$ & $3.915^{* * *}$ & $I(1)$ \\
$\Delta \ln \mathrm{AGING}$ & $-17.999^{* *}$ & $-2.982^{* *}$ & $0.165^{* *}$ & $5.170^{* *}$ & $I(1)$ \\
$\Delta \operatorname{lnSAV}$ & $-21.955^{* *}$ & $-3.312^{* *}$ & $0.150^{* *}$ & $4.156^{* *}$ & $I(1)$ \\
$\Delta \ln \mathrm{CONS}$ & $-23.117^{* *}$ & $-3.397^{* *}$ & $0.146^{* *}$ & $3.956^{* * *}$ & $I(1)$ \\
$\Delta \operatorname{lnFIN}$ & $-21.377^{* * *}$ & $-3.265^{* * *}$ & $0.152^{* * *}$ & $1.159^{* * *}$ & $I(1)$ \\
\hline
\end{tabular}

Note: The optimal lag length was selected automatically using SIC. ${ }^{* * *},{ }^{* *}$, and * denote significance at $1 \%, 5 \%$, and $10 \%$ levels, respectively 
Table 6. Lag length selection

\begin{tabular}{|c|c|c|c|c|c|}
\hline Lag & LR & FPE & AIC & SIC & HQ \\
\hline \multicolumn{6}{|c|}{ Panel A: Lag } \\
\hline 1 & 513.641 & $8.79 \mathrm{e}-17$ & -25.624 & -24.762 & -25.318 \\
\hline 2 & 102.207 & $6.20 \mathrm{e}-18^{*}$ & $-28.307^{*}$ & $-26.755^{*}$ & $-27.755^{*}$ \\
\hline 3 & $10.219^{*}$ & $1.03 \mathrm{e}-17$ & -27.873 & -25.632 & -27.076 \\
\hline 4 & 15.204 & $1.36 \mathrm{e}-17$ & -27.755 & -24.825 & -26.713 \\
\hline \multicolumn{6}{|c|}{ Panel B: Diagnostic tests for lag 2} \\
\hline \multicolumn{3}{|c|}{ Jarque-Bera normality test } & \multicolumn{3}{|c|}{$13.253(0.209)$} \\
\hline \multicolumn{3}{|c|}{ Serial correlation LM test } & \multicolumn{3}{|c|}{$32.209(0.163)$} \\
\hline \multicolumn{3}{|c|}{ Heteroskedasticity test } & \multicolumn{3}{|c|}{$613.219(0.345)$} \\
\hline
\end{tabular}

Note: * shows optimal lag length. The values in parentheses indicate the probabilities.

After examining the stationarity properties of the variables, a cointegration analysis was conducted. The results from the Johansen-Juselius cointegration test used in the study show that the series are cointegrated, meaning that a long-run relationship exists between the variables. Another test used in the study was the ARDL bounds test. The results of the ARDL bounds test showed that the $F$-statistic is higher than the UCB, meaning that the variables are cointegrated at a 5\% level. This indicates the presence of a longrun relationship among the variables. Therefore, this finding is in line with the results of the Johansen-Juselius test. The results of diagnostic tests used for the reliability of the ARDL model are reported in the lower part of Table 7. The findings reveal that the ARDL model has normal distribution and the residuals are free from problems of serial correlation and heteroskedasticity. In addition, the ARDL model is well specified.

Table 7. Johansen-Juselius cointegration test results

\begin{tabular}{cllll}
\hline $\begin{array}{l}\text { Null } \\
\text { hypothesis }\end{array}$ & $\begin{array}{l}\text { Trace } \\
\text { statistics }\end{array}$ & $\begin{array}{l}\text { Critical value at } \\
\mathbf{5} \%\end{array}$ & $\begin{array}{l}\text { Max. eigen } \\
\text { statistics }\end{array}$ & $\begin{array}{l}\text { Critical value } \\
\text { at 5 \% }\end{array}$ \\
\hline$H_{0}: r=0$ & $88.773^{* * *}$ & $69.818(0.000)$ & $38.103^{* *}$ & $33.876(0.014)$ \\
$H_{0}: r \leq 1$ & $50.669^{* *}$ & $47.856(0.026)$ & $25.281^{*}$ & $27.584(0.095)$ \\
$H_{0}: r \leq 2$ & 25.387 & $29.797(0.148)$ & 14.645 & $21.131(0.314)$ \\
$H_{0}: r \leq 3$ & 10.742 & $15.494(0.22)$ & 10.724 & $14.264(0.168)$ \\
$H_{0}: r \leq 4$ & 0.0183 & $3.841(0.892)$ & 0.018 & $3.841(0.892)$ \\
\hline
\end{tabular}

Note: $P$-values are in parentheses. 
Table 8. Bounds $F$-test results.

\begin{tabular}{|c|c|c|}
\hline Estimated model & $F(\ln G D P / \ln A G I N G, \ln S A V, \ln C O N S, \ln F I N)$ & \\
\hline Optimal lag structure & {$[1,2,0,0,1]$} & \\
\hline$F$-statistic & $5.26^{* *}$ & \\
\hline Cointegration & Yes & \\
\hline \multicolumn{3}{|c|}{ Pesaran et al. (2001) critical values for $F$-statistics } \\
\hline Significance level & Lower bounds, $I(0)$ & $\begin{array}{l}\text { Upper bounds, } \\
I(1)\end{array}$ \\
\hline $1 \%$ & 3.29 & 4.37 \\
\hline $5 \%$ & 2.56 & 3.49 \\
\hline $10 \%$ & 2.20 & 3.09 \\
\hline \multicolumn{3}{|c|}{ Narayan (2005) critical values for $F$-statistics } \\
\hline Significance level & Lower bounds, $I(0)$ & Upper bounds, $I(1)$ \\
\hline $1 \%$ & 4.30 & 5.87 \\
\hline $5 \%$ & 3.13 & 4.41 \\
\hline $10 \%$ & 2.61 & 3.74 \\
\hline \multicolumn{3}{|l|}{ Diagnostic tests } \\
\hline$R^{2}$ & 0.992 & \\
\hline Adj. $R^{2}$ & 0.990 & \\
\hline$F$-statistic & $592.563^{* * *}$ & \\
\hline $\begin{array}{l}\text { Breusch-Godfrey LN } \\
\text { test }\end{array}$ & $1.661(0.204)$ & \\
\hline ARCH LM test & $2.610(0.113)$ & \\
\hline J-B normality test & $0.105(0.948)$ & \\
\hline Ramsey RESET test & $0.158(0.254)$ & \\
\hline
\end{tabular}

Note: ${ }^{* * *}$ and ${ }^{* *}$ show significance at $1 \%$ and $5 \%$, respectively. The values in parentheses indicate the probabilities.

After investigating the cointegration between the variables, the effects of population aging, domestic savings, consumption expenditures, and financial development on economic growth, we estimated the long-run coefficients by applying the DOLS and CCR estimators. The long-run estimations are presented in Table 9y. The DOLS results show that population aging has a negative and statistically significant impact on economic growth. $1 \%$ percent increase in population aging causes a 1.619 percent decrease in economic growth. This finding coincides with the results of Choudhry and Elhorst (2010), who examined the impact of the demographic transition on economic growth for 70 countries over 1961-2003 through the panel data analysis and Ismail et al. (2016), who applied the ARDL approach in a case of Malaysia from 1980 to 2011. The study results revealed that population aging is negatively linked with economic growth. Maestas et al. (2014) for the USA and Bawazir, Aslam and Bin Osman (2020) for Middle East countries provided similar findings. Our finding is not consistent with the results of Huang et al. (2019), who dealt with the population aging-economic growth relationship for Taiwan during 1981- 
2017 by conducting a regression analysis. Neither is it consistent with Zhao et al. (2018), who examined the link among population aging, finance, and economic growth for 31 Chinese provinces from 2000 to 2016 by carrying out a panel data analysis. The studies showed that population aging positively affects economic growth over the period. However, Bloom et al. (2011) suggested that the impact of population aging on economic growth was not significant in developing countries.

It was found that domestic savings have a positive and statistically significant effect on economic growth. A 1 percent rise in domestic savings increases economic growth by 0.881 percent. This finding is consistent with the results of Uddin et al. (2016), who dealt with the link between population aging, domestic savings, and economic growth in the case of Australia from 1971 to 2014. The Dynamic Ordinary Least Square (DOLS) and Fully Modified Ordinary Least Squares (FMOLS) estimation results show that domestic savings rises economic growth in the long-run. In addition, Romm (2005) applied the Johansen and VECM approaches to deal with the savings-growth relationship for South Africa during 1946-1992. The study revealed that domestic savings are positively related to economic growth in the long-run.

It was also found that the impact of consumption expenditures on economic growth is positive and it is statistically significant. A 1 percent increase in consumption expenditures raises economic growth by 0.718 percent. This result does not coincide with the findings of Joshi, Pradhan and Bis (2019), who tested the relationship between domestic savings, investment, and economic growth in Nepal during 1975-2016, and Heitger (2001), who examined the relationship between government size and economic growth for OECD countries in 1960-2000. The findings of the studies revealed a negative link between consumption expenditures and economic growth by applying different econometric methods. Additionally, Hajamini and Falahi (2014) analyzed the link between consumption expenditure and economic growth in developing countries over 1981-2007. The empirical analysis indicated that a nonlinear relationship exists between the variables.

Finally, we found that financial development is negatively related to economic growth. A 1 percent rise in financial development decreases economic growth by 0.282 percent. This result is in line with the findings of Narayan and Narayan (2013), who explored the link between the financial system and economic growth for 65 developing countries by using regional panel techniques during 1995-2011 and Adua et al. (2013), who investigated the financial development-economic growth relationship in Ghana from 1961 to 2010. The findings indicated that financial development is negatively linked to economic growth in the long-run. Our result does not coincide with the findings of Ibrahim and Alagidede (2018), who tested the impact of financial development on economic growth in 29 Sub-Saharan Africa countries during 1980-2014. The 
Generalized Method of Moments (GMM) analysis result revealed that economic growth was determined by financial development in the long-run.

Table 9 also reports the CCR estimation findings. The findings taken from the CCR estimations are consistent with the results of the DOLS approach except for financial development.

Table 9. Long-run results

\begin{tabular}{lllllll}
\hline Estimation method & DOLS & & \multicolumn{3}{l}{ CCR } \\
\hline Variables & Coefficient & t-statistic & Prob. & Coefficient & t-statistic & Prob. \\
\hline Constant & $7.733^{* * * *}$ & 20.025 & 0.000 & $7.154^{* * * *}$ & 17.761 & 0.000 \\
lnAGING & $-1.619^{* * *}$ & -2.230 & 0.033 & $-0.717^{*}$ & -2.002 & 0.051 \\
lnSAV & $0.881^{* * *}$ & 3.804 & 0.000 & $0.482^{* *}$ & 2.687 & 0.010 \\
lnCONS & $0.718^{* * *}$ & 3.185 & 0.003 & $0.516^{* * *}$ & 2.841 & 0.006 \\
lnFIN & $-0.282^{*}$ & -1.721 & 0.096 & -0.078 & -0.597 & 0.553 \\
\hline Diagnostic tests & & & & & & \\
\hline $\mathrm{R}^{2}$ & 0.990 & & & 0.972 & & \\
Adj. $\mathrm{R}^{2}$ & 0.983 & & & 0.968 & & \\
SE of regression & 0.042 & & & 0.062 & & \\
SSR & 0.050 & & & 0.165 & & \\
\hline
\end{tabular}

Note: ${ }^{* * * *}, * *$ and ${ }^{*}$ show significance at $1 \%, 5 \%$, and $10 \%$, respectively.

The causality findings are reported in table 10 . The long-run causality results show that there is a bidirectional causal linkage between population aging and economic growth. This finding is in line with the results of Prskawetz, Kögel, Sanderson and Scherbov (2007), who examined the link between age structure and economic growth in India. The study suggests the presence of bidirectional causality between the variables. This finding contradicted the results of Uddin et al. (2016), who found unidirectional causality running from population aging to economic growth for Australia. The long-run results show that domestic savings and economic growth cause each other. This result was not supported by Uddin et al. (2016) for Australia.

The long-run causality results also show that domestic savings cause economic growth. This finding coincides with the results of Odhiambo (2009), who carried out a multivariate causality analysis for South Africa over 19502005, and Tang and Tan (2014), who used the Toda-Yamamoto causality approach in Pakistan from 1971 to 2011. Our result contradicted the findings of Patra, Murthy, Kuruva, and Mohanty (2017), who explored the causal linkage between domestic savings and economic growth during 1950-2011 by applying the VECM approach. The study found that economic growth caused domestic savings. It was found that there is bidirectional causality between consumption expenditures and economic growth in the long-run. This finding coincides with the results of Dritsakis and Adamopoulos (2004), who tested the relationship between government expenditures and economic development in the Greek 
economy during 1960-2001. However, our result contradicted the findings of Narayan, Rath and Narayan (2012), who analyzed Wagner's law for Indian states from 1997-2008. The panel Granger causality analysis indicated the existence of unidirectional causality running from economic growth to consumption expenditures in both the short-run and long-run.

Additionally, it was found that financial development and economic growth caused each other in the long-run. This finding is in line with the results of Ono (2017), who analyzed the financial development-economic growth link in Russia from 1999 to 2014 through the ARDL and Toda-Yamamoto procedures, and Wolde-Rufael (2009), who dwelled on the relationship between financial development and economic growth in Kenya during the period of 1966-2004 using the Toda-Yamamoto causality method. This finding contradicts the results of Ohlan (2017), who investigated the tourism-economic growth relationship by integrating financial development into the economic growth specification in India over 1960-2014. The finding of the study revealed the presence of unidirectional causality running from financial development to economic growth.

Table 10. Causality results

\begin{tabular}{|c|c|c|c|c|c|c|}
\hline \multirow[b]{2}{*}{$\begin{array}{l}\text { Dependent } \\
\text { variable }\end{array}$} & \multicolumn{5}{|c|}{$\begin{array}{l}\text { Short-run } \\
F \text {-statistic [p-value] }\end{array}$} & \multirow{2}{*}{$\begin{array}{l}\text { Long-run } \\
\text { t-statistic } \\
\text { [p-value] } \\
\text { ECT }_{\mathrm{t}-1}\end{array}$} \\
\hline & $\Delta \ln G D P$ & $\Delta \ln A G I N G$ & $\Delta \operatorname{lnSAV}$ & $\Delta \operatorname{lnCONS}$ & $\Delta \ln F I N$ & \\
\hline$\Delta \operatorname{lnGDP}$ & - & $\begin{array}{l}-0.699 \\
{[0.488]}\end{array}$ & $\begin{array}{l}0.910 \\
{[0.368]}\end{array}$ & $\begin{array}{l}1.947^{*} \\
{[0.058]}\end{array}$ & $\begin{array}{l}1.735^{*} \\
{[0.090]}\end{array}$ & $\begin{array}{l}-0.174^{* *} \\
{[0.025]}\end{array}$ \\
\hline$\Delta \ln A G I N G$ & $\begin{array}{l}1.762^{*} \\
{[0.085]}\end{array}$ & - & $\begin{array}{l}-0.631 \\
{[0.531]}\end{array}$ & $\begin{array}{l}-0.931 \\
{[0.357]}\end{array}$ & $\begin{array}{l}0.468 \\
{[0.641]}\end{array}$ & $\begin{array}{l}-0.061^{* * *} \\
{[0.000]}\end{array}$ \\
\hline$\Delta \ln \mathrm{SAV}$ & $\begin{array}{l}0.916 \\
{[0.365]}\end{array}$ & $\begin{array}{l}1.673 \\
{[0.102]}\end{array}$ & - & $\begin{array}{l}-2.593^{* *} \\
{[0.013]}\end{array}$ & $\begin{array}{l}0.780 \\
{[0.439]}\end{array}$ & $\begin{array}{l}-0.299^{* *} \\
{[0.034]}\end{array}$ \\
\hline$\Delta \operatorname{lnCONS}$ & $\begin{array}{l}0.746 \\
{[0.460]}\end{array}$ & $\begin{array}{l}1.308 \\
{[0.198]}\end{array}$ & $\begin{array}{l}3.224^{* * *} \\
{[0.002]}\end{array}$ & - & $\begin{array}{l}-1.381 \\
{[0.174]}\end{array}$ & $\begin{array}{l}-0.298^{\text {*** }} \\
{[0.048]}\end{array}$ \\
\hline$\Delta \ln F I N$ & $\begin{array}{l}0.284 \\
{[0.777]}\end{array}$ & $\begin{array}{l}0.395 \\
{[0.694]}\end{array}$ & $\begin{array}{l}0.007 \\
{[0.994]}\end{array}$ & $\begin{array}{l}-1.834^{*} \\
{[0.074]}\end{array}$ & - & $\begin{array}{l}-0.418^{* *} \\
{[0.010]}\end{array}$ \\
\hline
\end{tabular}

Note: ${ }^{* * *},{ }^{* *}$, and ${ }^{*}$ show significance at $1 \%, 5 \%$, and $10 \%$, respectively.

\section{CONCLUSION AND POLICY IMPLICATION}

Technological improvements, decline in child mortality rate, decreased infant mortality rate, increased quality of life and prolonged life, more participation of women in the labor force, and increased education level have accelerated the aging of the population in the world and also in Turkey. Social, economic, and health problems caused by an aging population have started to be 
among the priority issues of countries. Considering Turkey's rate of aging, although it is very low compared to other countries, it will reach a $14 \%$ rate of aging in the next 20 years. According to Coulmas's work in 2007, although most countries have already reached an aging society, especially developed countries, Turkey is expected to reach this status in 2040. This study examined the relationship between population aging and economic growth in Turkey during 1970-2018 by using time-series analysis. To assess this relationship, we integrated domestic savings, consumption expenditures, and financial development into the growth specification as additional variables. We use the $\mathrm{Ng}$-Perron unit root tests to examine for stationarity analysis. We also used the Johansen and ARDL bounds test for cointegration analysis. This study applied two alternative estimation methods, such as DOLS and CCR. Finally, we applied the VECM procedure for causality analysis. The findings indicated that population aging has a negative and significant impact on economic growth implying that population aging decreases economic growth in the long-run. The causality analysis showed that population aging, and economic growth cause each other in the long-run. According to the results, Turkey will be confronted by an aging population in the future, which may be a burden for Turkey's economy. The following policies are recommended to weaken this burden:

- The second policy proposal is to make important investments in the field of healthcare to improve the health of the elderly. These investments reduce the burden on health and social security systems and enable them to have a healthy body to continue working in old age. As a result of this policy, it will be ensured that the elderly will not only ease the burden on public funding but also contribute to the economies according to their skills and knowledge. The findings also indicate that domestic savings and consumption expenditures have a positive and significant impact on economic growth, meaning that they increase economic growth in the long-run. The causality analysis also shows that there is a bidirectional causal linkage between the variables.

- According to these findings, another policy would be to investigate the consumption market of the elderly. As the aging population's share in the total population will increase, companies will need to develop their new products according to this group. Since new market areas will be created, the countries that are pioneers in this field, which have developed and patented new products with studies, will have an advantage. Furthermore, by affecting consumer behavior, the consumption trends of the elderly will be determined and encouraged to demand. It should be known that soon, the sector that will have the highest purchasing power would be the elderly sector.

- In addition, with the prolongation of life expectancy, individuals can be influenced by uncertainties and therefore, tend to save more by thinking about their future. 
We found that financial development has a negative and significant effect on economic growth, implying that financial development reduces economic growth in the long-run. We also found that bidirectional causality exists between the variables. The reason why the excessive money supply put into the market negatively affects economic growth can be attributed to its idle use. Therefore, several tasks should be assigned to the government to use this money proficiently and effectively. Policies that facilitate access to affordable loans for businesses can be followed and difficulties in accessing credit for elderly individuals should be eliminated.

We see that some countries in the last century have coped well with the policies they have applied to the major demographic change represented by aging of the population. Turkey's current policymakers should take the necessary measures immediately to minimize the effects of aging and be ready to overcome the problems that they will face later. Hereby, contrary to what is thought as in the results, aging can cause positive effects on the economy. It should not be forgotten that healthy and vigorous elderly people also contribute to the economy similar to the contribution of a young society. Just as youth participation in the workforce is seen as normal, as long as their health condition permits, a system should be created in which elderly in work is considered normal. Future studies may incorporate other population aging criteria, such as fertility rate and life expectancy in a growth model. In addition, several emerging countries should be included in these studies. Therefore, it will be possible to get more robust findings and policy implications

\section{REFERENCES}

Acemoglu, D., and Restrepo, P. (2017). Secular stagnation? The effect of aging on economic growth in the age of automation. American Economic Review, 107(5), 174-79.

Adua, G., Marbuah, G. and Mensah, J.T. (2013). Financial development and economic growth in Ghana: Does the measure of financial development matter? Review of Development Finance, 3(4), 192-203. http://dx.doi.org/10.1016/j.rdf.2013.11.001.

Aghion, P., Comin, D., Howitt, P., and Tecu, I. (2009). When Does Saving Matter for Economic Growth? Harvard Business School Working Paper, 09-080.

Aksoy, Y., Basso, H. S., Smith, R., and Grasl, T. (2015). Demographic structure and macroeconomic trends. Madrid, Spain: Banko de Espana.

Bailey, M.J. (1971). National Income and the Price Level: A Study in Macroeconomic Theory. USA: Mc Graw-Hill: New York. 
Bawazir, A.A.A., Aslam, M. and Bin Osman, A.F. (2020). Demographic change and economic growth: empirical evidence from the Middle East. Economic Change and Restructuring, 53, 429-450. https://doi.org/10.1007/s10644-019-09254-8 .

Bhargava, A. (1986). On the theory of testing for unit roots in observed time series. Review of Economic Studies, 52, 369-384.

Bloom, D. E., Canning, D., \& Finlay, J. E. (2010). Population aging and economic growth in Asia. Takatoshi Ito and Andrew Rose (Eds.). In the economic consequences of demographic change in east Asia (pp. 61-89). Chicago, USA: University of Chicago Press.

Bloom, D. E., Canning, D., \& Fink, G. (2011). Implications of population aging for economic growth. Harvard program and the global demography of aging working. 64, 2011.

Caceres, L.R. (1995). Foreign resources, domestic savings and economic growth: The case of Central America, Savings and Development, 19(4), 393-404. http://www.jstor.com/stable/25830555

Cetin, M., Ecevit, E., \& Yucel, A. G. (2018). Structural breaks, urbanization and $\mathrm{CO} 2$ emissions: Evidence from Turkey. Journal of Applied Economics and Business Research, 8(2), 122-139.

Cervellati, M., and Sunde, U. (2009). Life expectancy and economic growth: the role of the demographic transition. Journal of economic growth, 16(2), 99-133.

Choudhry, M. T., and Elhorst, J. P. (2010). Demographic transition and economic growth in China, India, and Pakistan. Economic Systems, 34(3), 218-236.

Coile, C., Diamond, P., Gruber, J., and Jousten, A. (2002). Delays in claiming social security benefits. Journal of Public Economics, 84(3), 357-385.

Coulmas, F. (2007). Population decline and aging in Japan-the social consequences, USA, Canada: Routledge.

Devereux, M., \& Smith, G. (1994). International risk-sharing and economic growth. International Economic Review, 35, 535-550.

Dritsakis, N. and Adamopoulos, A. (2004). A causal relationship between government spending and economic development: an empirical examination of the Greek economy. Applied Economics, 36, 457-464. https://doi.org/10.1080/00036840410001682151.

Elliott, G., Rothenberg, T.J. and Stock, J.H. (1996). Efficient tests for an autoregressive unit root. Econometrica, 6, 813-836. 
Ecevit, E., Çetin, M., \& Yücel, A. G. (2018). Türki Cumhuriyetlerinde sağlık harcamalarının belirleyicileri: Bir panel veri analizi. Akademik Araştırmalar ve Çalışmalar Dergisi, 10(19), 318-334. https://doi.org/10.20990/kilisiibfakademik.407522

Engle, RF Granger, CWJ (1987). Co-integration and error correction: Representation, estimation, and testing. Econometrica: Journal of the Econometric Society, 55, 251- 276

Eren, B.M., Taspinar, N. and Gokmenoglu, K.K. (2019). The impact of financial development and economic growth on renewable energy consumption: Empirical analysis of India. Science of the Total Environment, 663, 189197.https://doi.org/10.1016/j.scitotenv.2019.01.323

Fougère, M., and Mérette, M. (1999). Population aging and economic growth in seven OECD countries, Economic Modelling, 16(3), 411-427.

Günsoy, G., and Tekeli, S. (2015). Nüfusun Yaşlanması ve Ekonomik Büyüme İlişkisi: Türkiye Üzerine Bir Analiz, Amme İdaresi Dergisi, 48(1).

Hajamini, M. and Falahi, M.A. (2014) The nonlinear impact of government consumption expenditure on economic growth: Evidence from low and low-middle income countries. Cogent Economics \& Finance, 2,1-15. https://doi.org/10.1080/23322039.2014.948122.

Heitger, B. (2001). The scope of government and its impact on economic growth in OECD Countries. Kiel Institute of World Economics.

Hsu, Y. H., and Lo, H. C. (2019). The Impacts of Population Aging on Saving, Capital Formation, and Economic Growth, American Journal of Industrial and Business Management, 9(12), 2231.

Huang, W. H., Lin, Y. J., and Lee, H. F. (2019). Impact of Population and Workforce Aging on Economic Growth: Case Study of Taiwan, Sustainability, 11(22), 6301.

Ibrahim, M. and Alagidede, P. (2018). Effect of financial development on economic growth in Sub-Saharan Africa. Journal of Policy Modeling, 40, 1104-1125.https://doi.org/10.1016/j.jpolmod.2018.08.001.

Ihori, T., Kato, R. R., Kawade, M., and Bessho, S. I. (2005). Public debt and economic growth in an aging Japan. In Tackling Japan's Fiscal Challenges (pp. 30-68). Palgrave Macmillan, London.

Ismail, N. W., Abd Rahman, H. S. W. H., Hamid, T. A. T. A., and Said, R. (2016). Aging and Economic Growth: Empirical Analysis using Autoregressive Distributed Lag Approach. Sains Malaysiana, 45(9), 1345-1350. 
Johansen, S. (1988). Statistical analysis of cointegration vectors. Journal of economic dynamics and control, 12(2-3), 231-254.

Johansen, S., and Juselius, K. (1994). Identification of the long-run and the short-run structure an application to the ISLM model. Journal of Econometrics, 63(1), 7-36.

Joshi, A., Pradhan, S., and Bis, J.P. (2019). Savings, investment, and growth in Nepal: an empirical analysis. Financial Innovation, 5(39), 1-13. https://doi.org/10.1186/s40854-019-0154-0.

Kinugasa, T. and Mason, A. (2007). Why Countries Become Wealthy: The Effects of Adult Longevity on Saving. World Development, 35, 1-23.

Landau, D. (1983). Government Expenditure and Economic Growth: A CrossCountry Study. Southern Economic Journal, 49 (3), 783-792. http://www.jstor.com/stable/1058716.

Lee, H. H., and Shin, K. (2019). Nonlinear effects of population aging on economic growth. Japan and the World Economy, 51, 100963.

Lindh, T., and Mralmberg, B. (1999). Age structure effects and growth in the OECD, 1950-1990. Journal of Population Economics, 12(3), 431-449.

Maestas, N., Mullen, K. J., and Powell, D. (2016). The effect of population aging on economic growth, the labor force, and productivity. National Bureau of Economic Research. (22452).

Mehmood, B. and Shahid, A. (2014). Aviation Demand and economic growth in the Czech Republic: Cointegration Estimationand Causality Analysis. Statistika, 94(1), 54-63.

Mitic, P., Ivanovic, O.M. and Zdravkovic, A. (2014). A Cointegration Analysis of Real GDP and $\mathrm{CO}_{2}$ Emissions in Transitional Countries. Sustainability, 9(568), 1-18.

Narayan, S., Rath, B.N. and Narayan, P.K. (2012). Evidence of Wagner's law from Indian states. Economic Modelling, 29, 1548-1557. https://doi.org/10.1016/j.econmod.2012.05.004.

Narayan, P.K. and Narayan, S. (2013). The short-run relationship between the financial system and economic growth: New evidence from regional panels. International Review of Financial Analysis, 29, 70-78. http://dx.doi.org/10.1016/j.irfa.2013.03.012.

Ng, S., and Perron, P. (2001). Lag length selection and the construction of unit root tests with good size and power. Econometrica, 69(6), 1519-1554. 
Odhiambo, N.M. (2009). Savings and economic growth in South Africa: A multivariate causality test. Journal of Policy Modeling, 31, 708-718. http://dx.doi.org/10.1016/j.jpolmod.2009.04.001.

Ohlan, R. (2017). The relationship between tourism, financial development, and economic growth in India. Future Business Journal, 3, 9-22. http://dx.doi.org/10.1016/j.fbj.2017.01.003.

Ono, S. (2017). Financial development and economic growth nexus in Russia. Russian Journal of Economics, 3, 321-332. http://dx.doi.org/10.1016/j.ruje.2017.09.006.

Park, D., \& Shin, K. (2012). Impact of population aging on Asia's future growth. In Aging, Economic Growth, and Old-Age Security in Asia. Mandaluyong, Philippines: Edward Elgar Publishing.

Patra, S.S., Murthy, D.S., Kuruva, M.B. and Mohanty, A. (2017). Revisiting the causal nexus between savings and economic growth in India: An empirical analysis. Economia, 380-391. http://dx.doi.org/10.1016/j.econ.2017.05.001.

Pesaran, M. H., Shin, Y., and Smith, R. J. (2001). Bounds testing approaches to the analysis of level relationships. Journal of applied econometrics, 16(3), 289-326.

Philips, B., and Perron, P. (1988). Mean Reversion in Stock Prices. Journal of Financial Economics, 22, 27-59.

Prskawetz, A., Kögel, T., Sanderson., WC and Scherbov, S. (2007). The effects of age structure on economic growth: An application of probabilistic forecasting to India. International Journal of Forecasting, 23(4), 587-602.

Romm, A.T. (2005). The relationship between saving and growth in South Africa: A time series analysis. South African Journal of Economics, 73(2), 171-189.

Shahbaz, M., Afza, T., Shabbir, S. M. (2011). Does defense spending impede economic growth? cointegration and causality analysis for Pakistan. MPRA Paper. 30887.

Shaw, E.S. (1973). Financial Deepening in Economic Development, New York, USA : Oxford University Press.

Stock, J. H., and Watson, M. W. (1993). A simple estimator of cointegrating vectors in higher order integrated systems. Econometrica: Journal of the Econometric Society, 783-820.

Tang, C.F. and Tan, B.W. (2014). A revalidation of the savings-growth nexus in Pakistan. Economic Modelling, 36, 370-377. http://dx.doi.org/10.1016/j.econmod.2013.10.012. 
Turkish Statistical Institute. (2019). Workforce indicator. Access address:http://www.turkstat.gov.tr/Start.do,

Uddin, G.A., Alam, K. and Gow, J. (2016). Population age structure and savings rate impacts oneconomic growth: Evidence from Australia.Economic Analysis and Policy, 2333.http://dx.doi.org/10.1016/j.eap.2016.08.002.

World Bank. (2020), World Development Indicators Database. Access address: https://data.worldbank.org.

World Health Organization. (2020). Under-five mortality. Access address:www.who.int/gho/child_health/mortality/mortality_under_five_te $\underline{\mathrm{xt} / \mathrm{en} / .}$.

Wolde-Rufael, Y. (2009). Re-examining the financial development and economic growth nexus in Kenya. Economic Modelling, 26, 1140-1146. http://dx.doi.org/10.1016/j.econmod.2009.05.002.

Zhao, Y., Xu, X., Zhang, X., and Xia, S. (2018). Identifying the impacts of social, economic, and environmental factors on population aging in the Yangtze River Delta using the geographical detector technique. Sustainability, 10(5), 1528. 
